\title{
EFFECT OF AQUEOUS AND ALCOHOLIC EXTRACTS OF COTTONSEED ON SOME PARAMETERS OF SPERMS AND REPRODUCTIVE PERFORMANCE OF ALBINO MICE.
}

\author{
Inaam Noori Ali" ${ }^{*}$ Mohammad Baqir M.R. Fakhrildin ${ }^{* *}$ and Sabah A.R.Al-Obaidi*** \\ *Water Laboratories Researches Centre, Environment \& Water Res. \& Tech. Directorate, \\ Ministry of Science and Technology. \\ ** Department of Clinical Physiology, Institute of Embryo Research and Infertility \\ Treatment, Al-Nahrain University. \\ **** Department of Biology, College of Science for Women, University of Baghdad.
}

\begin{abstract}
Two cottonseed extracts including alcoholic and aqueous at doses 20 and $40 \mathrm{mg} / \mathrm{Kg} / \mathrm{day}$ were orally administered to male mice for 6 weeks to study their effects on some of sperm parameters. Results showed that 20 and $40 \mathrm{mg} / \mathrm{kg}$ alcoholic and aqueous extract caused highly significant $(\mathrm{P} \leq 0.01)$ decrease in the sperm concentration, motility $(\%)$ and progressive sperm motility $(\%)$. While, Results of the abnormal sperm morphology (\%) for two treated groups 20 and $40 \mathrm{mg} / \mathrm{kg} / \mathrm{day}$ of alcoholic and aqueous extracts revealed a significant $(\mathrm{P} \leq 0.05)$ increase after 6 weeks when compared to the control group. Results revealed that the percentages of sperm agglutination were highly significant $(\mathrm{P} \leq 0.01)$ increased in mice treated with 20 and $40 \mathrm{mg} / \mathrm{kg} / \mathrm{day}$ of alcoholic and aqueous when compared to the control. The fertility $(\%)$ and percentage of males of new born babies showed a significant $(\mathrm{P} \leq 0.05)$ reduction in the treated mice as compared to female in the same groups and to the control group. Meanwhile, a significant $(\mathrm{P} \leq 0.05)$ increase in the recovery time was showed with the increasing of doses of the two extracts when compared with the control group.
\end{abstract}

Keywords: Cottonseed extracts, mice, sperm function test, reproduction.

\section{Introduction}

Cottonseed is crushed to produce cottonseed oil, cottonseed meal and hulls, it contains a fixed oil, which is about $2 \%$ gossypol [1]. Whole cottonseed (WCS) and cottonseed meal (CSM) are valuable feedstuffs, providing important sources of protein and energy for ruminant animals $[2,3]$.

Cottonseed contains $7 \%$ moisture, $23 \%$ protein, $23 \%$ fat, $3 \%$ minerals, $24 \%$ fiber, and $20 \%$ carbohydrate [4]. Also, cottonseed contains: phosphorus, calcium, iron, potassium, magnesium, sodium, manganese, aluminum, silica, sulphur, chlorine, copper (trace), boron, zinc and iodine. In addition to vitamins such as B-complex A, D and E [5]. Nine flavonol glycosides have been identified from whole cottonseed by-product, some of them are dihydroxybenzoic acid, gallic acid, guercetin [6].

The natural product (gossypol) has been used by fertile men in China as an effective male contraceptive agent for many years, its antifertility effects on reproductive endocrine tissues are observed at 1000-fold lower doses than its toxic effects in other tissues [7]. Gossypol causes decrease or an inhibition of sperm motility, decrease of sperm concentration, an increase in sperm abnormalities and an inhibition of testicular steroidogenesis $[8,9]$. The aim of the present study was to investigate the effect of alcoholic and aqueous extracts on sperm function tests such as sperm concentration, motility, morphology and agglutination in addition to the reproductive capacity.

\section{Materials and Methods}

Mature male Swiss albino mice were obtained from the animal house of the Institute of Embryo Research and Infertility Treatment, Al-Nahrain University. The average weight of mice was $24 \pm 1 \mathrm{~g}$. They were kept in an air conditioned room $\left(22-24{ }^{\circ} \mathrm{C}\right)$ with an automatically controlled photoperiod of 16 hours (hrs) light and 8 hrs darkness. Mice 
were fed with the standard balanced pellet diet that prepared in the animal house of the above Institute and given tap water ad libitum.

\section{Preparation of cotton seed extracts}

Cottonseeds (Ashour1, Lashata and Coker 310) were obtained from the general company for industrial crops, Baghdad. Seeds were cleaned, dried then powdered with a grinder.

\section{Aqueous extract of cottonseed}

Fifty grams of the dry powder of cottonseed were mixed with $500 \mathrm{ml}$ of cold distilled water in a closed vessel and subjected to a continuous mixing for $24 \mathrm{hr}$ at $40{ }^{\circ} \mathrm{C}$ using magnetic stirrer. The whole mixture was filtered by a piece of gauze, and followed by centrifugation at 3000 r.p.m for $15 \mathrm{~min}$, then, filtered through filter paper (Whatman No.1) and dried by placing it in the oven under $40-45{ }^{\circ} \mathrm{C}$ for $24 \mathrm{hr}$. The dried material was weighed and stored in dark place until use [10].

\section{Alcoholic extract of cottonseed}

Fifty grams of the dry powder of cottonseed were extracted by ethyl alcohol. These cottonseeds were added to thumble tube in the soxhlet apparatus with $500 \mathrm{ml}$ of the ethyl alcohol at concentration of $95 \%$, then the mixture was transfer to the rotary evaporator under a reduced pressure at $60{ }^{\circ} \mathrm{C}$ for evaporation of alcohol, and then dried by putting it in the oven under $45^{\circ} \mathrm{C}$ for $24-36 \mathrm{hr}$. to obtain the dried extracted powder [11].

\section{Experimental design}

The experimental mice were divided randomly into five experimental groups. Each group consisted of 14 mice:

Group (1): served as control under similar condition and orally administered with $0.05 \mathrm{ml}$ normal saline/animal /day.

Group (2): orally received alcoholic extract of cottonseed $(20 \mathrm{mg} / \mathrm{kg} \mathrm{b} . \mathrm{wt})$, given at $0.05 \mathrm{ml} /$ animal/ day.

Group (3): orally received alcoholic extract of cottonseed $(40 \mathrm{mg} / \mathrm{kg}$ b.wt), given at $0.05 \mathrm{ml} /$ animal/ day.

Group (4): orally received aqueous extract of cottonseed $(20 \mathrm{mg} / \mathrm{kg}$ b.wt), given at $0.05 \mathrm{ml} /$ animal/ day.
Group (5): orally received aqueous extract of cottonseed $(40 \mathrm{mg} / \mathrm{kg}$ b.wt), given at $0.05 \mathrm{ml} / \mathrm{animal} / \mathrm{day}$.

\section{Sperm Parameters:}

Study of the mouse sperm parameters were performed for 9 males per group after the end of the experiment, using both left and right epididymes of each male. They were collected and washed with normal saline then put in a small petri dishes containing about $1 \mathrm{~mL}$ of sperm preparation medium the components of the medium is shown in Table (1). Both epididymes were minced with a microsurgical scissor until getting a homogenized solution which contains the spermatozoal suspension. The obtained suspension was incubated at $37^{\circ} \mathrm{C}$ until examination [12], and the following parameters were used: sperm concentration, it estimated by [13]; sperm motility and progress motility, they calculated according to [14], sperm morphology, this method was prepared according to [15]; sperm agglutination, it was determine according to [16].

\section{Reproductive capacity and recovery time:}

Natural mating of each of five males per group, mated with 10 fertile and healthy females ( 2 females per each male), had achieved the evaluation of reproductive capacity of the mated males and the following parameters were recorded: fertility percentage, litter size, No. of pregnant females and sex ratio.

\section{Statistical Analysis:}

Statistical analysis was performed with the Statistical Package for Social Sciences Software (SPSS; version 14.0, USA). Differences between groups were examined by ANOVA test (analysis of variance of means) with mean and standard error (S.E.). Pearson Chi-square test was applied to calculate the sex percentage and fertility parameters by using Statistical Analysis System (SAS). P value $<0.05$ and 0.01 were considered as statistically significant and highly significant respectively. 
Table (1)

The content of Modified Earl's medium used in this study.

\begin{tabular}{|c||c||}
\hline Ingredients & Weights \\
\hline \hline Earl's salt & $0.884 \mathrm{~g}$ \\
\hline \hline Ampicillin & $0.008 \mathrm{~g}$ \\
\hline Sodium pyruvate & $0.001 \mathrm{~g}$ \\
\hline \hline Sodium bicarbonate & $0.21 \mathrm{~g}$ \\
\hline water & $\mathrm{Up}$ to $100 \mathrm{~mL}$ \\
\hline Osmolarity & $280-290 \mathrm{mosmol} / \mathrm{L}$ \\
\hline \hline $\mathrm{pH}$ & 7.4 \\
\hline \hline Temperature & 23 to $25^{\circ} \mathrm{C}$ \\
\hline
\end{tabular}

Results

The alcoholic and aqueous extracts of cottonseed given orally using stomach tube at doses of $20 \mathrm{mg} / \mathrm{Kg}$ and $40 \mathrm{mg} / \mathrm{Kg}$ caused highly significant $(\mathrm{P} \leq 0.01)$ decline in the sperm concentration after 6 weeks of treatment as compared to the control group (G1) (Tables 2 and 3$)$. Highly significant $(\mathrm{P} \leq 0.01)$ reduction was noticed in the percentages of sperm motility and progressive sperm motility after the 6 weeks of administration of alcoholic and aqueous extracts of cottonseed at doses of 20 and $40 \mathrm{mg} / \mathrm{Kg} /$ day as compared to the control group (Tables 2 and 3 ).
Results of the sperm abnormality (\%) for two treated groups 20 and $40 \mathrm{mg} / \mathrm{kg} /$ day of alcoholic and aqueous extracts revealed a significant $(\mathrm{P} \leq 0.05)$ increase after 6 weeks when compared to the control group (Tables 2 and 3). Results of sperm agglutination revealed that the percentages of sperm agglutination were increased significantly $(\mathrm{P} \leq 0.01)$ rather than the control in mice treated with 20 and $40 \mathrm{mg} / \mathrm{kg} /$ day of alcoholic and aqueous extract. Results of reproductive capacity of treated males showed a remarkable decrease in each of number of pregnant females and new born babies in all treated groups as compared to the control group. Also, a significant $(\mathrm{P} \leq 0.05)$ decrease was shown in the litter size in all treated groups as compared with the control groups (Tables 4 and 5). The same tables, the fertility (\%) showed a significant $(\mathrm{P} \leq 0.05)$ reduction in all treated groups when compared with the control. However, percentage of males of new born babies showed a significant $(\mathrm{P} \leq 0.05)$ reduction in all treated groups as compared to female in the same groups and to the control group. Meanwhile, a significant $(\mathrm{P} \leq 0.05)$ increase in the recovery time was showed with the increasing of doses of the three extracts when compared with the control group (Tables 4 and 5).

Table (2)

Parameters of epididymal sperm (Mean \pm S.E) for male mice received two concentrations of alcoholic extraction of cottonseeds for six weeks.

\begin{tabular}{|c|c|c|c|}
\hline \multirow[b]{2}{*}{ Parameters } & \multirow[b]{2}{*}{$\begin{array}{c}G 1 \\
\text { (control) }\end{array}$} & \multicolumn{2}{|c|}{ Alcoholic extract } \\
\hline & & $\begin{array}{c}G 2 \\
(20 \mathrm{mg} / \mathrm{kg})\end{array}$ & $\begin{array}{c}G 3 \\
(40 \mathrm{mg} / \mathrm{kg})\end{array}$ \\
\hline $\begin{array}{c}\text { Sperm concentration } \\
(\text { million } / \mathbf{m L})\end{array}$ & $49.84 \pm 0.94^{\mathrm{a}}$ & $35.00 \pm 1.34^{\mathbf{b}^{*}}$ & $33.03 \pm 2.04^{\mathbf{b}^{*}}$ \\
\hline Sperm motility (\%) & $68.46 \pm 1.26^{\mathrm{a}}$ & $47.29 \pm 2.10^{\mathbf{b}^{*}}$ & $46.84 \pm 1.47^{\mathbf{b}^{*}}$ \\
\hline $\begin{array}{l}\text { Progressive sperm } \\
\text { motility }(\%)\end{array}$ & $62.91 \pm 2.18^{\mathrm{a}}$ & $41.40 \pm 1.72^{\mathbf{b}^{*}}$ & $39.49 \pm 1.88^{\mathbf{b}^{*}}$ \\
\hline $\begin{array}{l}\text { Abnormal Sperm } \\
\text { morphology }(\%)\end{array}$ & $29.73 \pm 1.34^{\mathrm{a}}$ & $37.89 \pm 2.35^{\mathbf{b}}$ & $39.16 \pm 2.35^{\mathbf{b}}$ \\
\hline $\begin{array}{c}\text { Sperm agglutination } \\
(\%)\end{array}$ & $25.54 \pm 0.96^{\mathrm{a}}$ & $39.29 \pm 0.51^{\mathbf{b}^{*}}$ & $39.70 \pm 0.82^{\mathbf{b}^{*}}$ \\
\hline
\end{tabular}

Different letters at the same row are significantly $(P \leq 0.05)$ different.

Different letters with * are highly significant $(P \leq 0.01)$ difference with control. 
Table (3)

Parameters of epididymal sperm (Mean \pm S.E) for male mice received two concentrations of aqueous extraction of cottonseeds for six weeks.

\begin{tabular}{|c|c|c|c|}
\hline \multirow[b]{2}{*}{ Parameters } & \multirow{2}{*}{$\begin{array}{c}G 1 \\
(\text { Control })\end{array}$} & \multicolumn{2}{|c|}{ Aqueous extract } \\
\hline & & G4 $(20 \mathrm{mg} / \mathrm{kg})$ & $\begin{array}{c}G 5 \\
(40 m g / k g)\end{array}$ \\
\hline $\begin{array}{c}\text { Sperm concentration } \\
(\mathrm{million} / \mathrm{mL})\end{array}$ & $49.84 \pm 0.94^{\mathrm{a}}$ & $36.16 \pm 1.54^{b^{*}}$ & $34.54 \pm 1.25^{b^{*}}$ \\
\hline Sperm motility (\%) & $68.46 \pm 1.26^{\mathrm{a}}$ & $49.53 \pm 3.15^{\mathbf{b}^{*}}$ & $47.50 \pm 1.04^{\mathbf{b}^{*}}$ \\
\hline $\begin{array}{l}\text { Progressive sperm } \\
\text { motility }(\%)\end{array}$ & $62.91 \pm 2.18^{\mathrm{a}}$ & $44.49 \pm 3.14^{\mathbf{b}^{*}}$ & $42.95 \pm 1.94^{\mathbf{b}^{*}}$ \\
\hline $\begin{array}{l}\text { Abnormal Sperm } \\
\text { morphology (\%) }\end{array}$ & $29.73 \pm 1.34^{\mathrm{a}}$ & $37.77 \pm 2.88^{\mathbf{b}}$ & $38.37 \pm 0.83^{\mathbf{b}}$ \\
\hline Sperm agglutination $(\%)$ & $25.54 \pm 0.96^{\mathrm{a}}$ & $36.52 \pm 2.59^{\mathbf{b}^{*}}$ & $40.64 \pm 0.27^{\mathrm{c}^{*}}$ \\
\hline
\end{tabular}

Each value represents mean \pm S.E.

Means having different letters at the same row are significantly $(P<0.05)$ different.

Means having different letters with * are highly significant $(P<0.01)$ difference with control.

Table (4)

Effect of the alcoholic extract of cottonseed (orally administered to mature male mice for six weeks) on fertility parameters (Mean \pm S.E) after mating with female mice.

\begin{tabular}{|c|c|c|c|c|c|}
\hline \multirow[b]{2}{*}{ Parameters } & \multirow[t]{2}{*}{ Groups } & \multirow{2}{*}{$\begin{array}{c}\text { G1 } \\
\text { Control }\end{array}$} & \multicolumn{3}{|c|}{ Alcoholic extract } \\
\hline & & & $\begin{array}{c}G 2 \\
20 m g / k g\end{array}$ & $\begin{array}{c}G 3 \\
40 \mathrm{mg} / \mathrm{kg}\end{array}$ & LSD value \\
\hline \multicolumn{2}{|c|}{ Recovery time (Days) } & $1.5 \mathrm{a}$ & $2.3 \quad \mathbf{a b}$ & 3.1 & $1.024 *$ \\
\hline \multicolumn{2}{|c|}{ Fertility (\%) } & $100 \quad \mathbf{a}$ & 70 & 70 & $7.556 *$ \\
\hline \multicolumn{2}{|c|}{$\begin{array}{l}\text { No. of pregnant } \\
\text { females }\end{array}$} & 10 & 7 & 7 & - \\
\hline \multicolumn{2}{|c|}{ Litter size } & $7.7 \quad \mathbf{a}$ & 5.29 & 5.0 & $1.667 *$ \\
\hline \multirow{2}{*}{$\begin{array}{c}\text { Sex } \\
\text { percentage } \\
(\%)\end{array}$} & Male & $64.93^{\mathrm{a}}$ & 43.24 & 48.57 & $6.45 *$ \\
\hline & $\begin{array}{c}\text { Femal } \\
\mathrm{e}\end{array}$ & $35.07 \quad \mathbf{a}$ & 56.76 & 51.43 & $6.052 *$ \\
\hline
\end{tabular}

No. of female for each group $=10$.

Different letters at the same row are significantly $(P \leq 0.05)$ different.

Same letters at the same row are non significant $(P>0.05)$ difference. 
Table (5)

Effect of the aqueous extract of cottonseed orally administered to mature male mice for six weeks on fertility parameters (Mean \pm S.E) after mating with female mice.

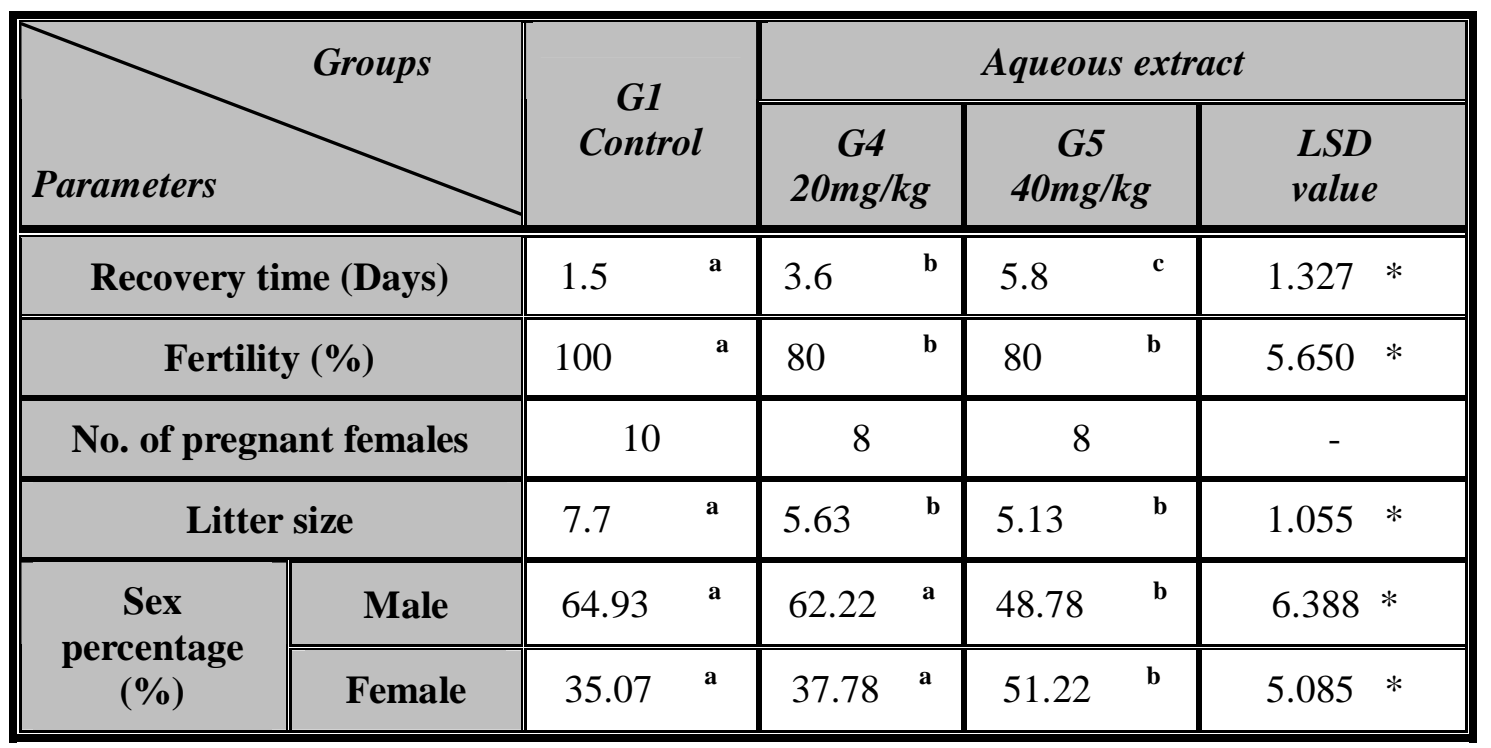

No. of female for each group $=10$.

Different letters at the same row are significantly $(P \leq 0.05)$ different.

Same letters at the same row are non significant $(P>0.05)$ difference.

\section{Discussion}

The present study revealed that there was a significant reduction in the epididymal sperm concentration in mice after six weeks period of cottonseed extracts treatment. One of the most important explanations of this was investigated by $[17,18]$, suggested that damage of the germ cells, detachment of spermatogonia from the basement membrane and shedding of immature spermatid contributed to the low spermatic density and sperm production in both seminiferous and epididymal tubules in cottonseed treated mice. Study of [19] showed that the testis is the main target organ of gossypol toxicity following repeated exposure, which the reduction of sperm counts and motility are time and dose-dependant.

The reduction in the sperm concentration may be explained by the reduction of serum testosterone, thus impaired spermatogenesis associated with testosterone deficiency [20, 21]. Results of [22] showed that the reduction of sperm concentration may related to direct binding of gossypol with spermatozoal membrane which lead to the loss of fluidity and elasticity of membrane with facilitate the cell destruction through increase fragility of membrane in the bulls. The reduction in the sperm motility may be due to reduction of mitochondrial activity under gossypol activity $[23,24]$. While [25] attributed the reduction of rapidly moving sperms to impairment dyneinATPase system on microtubular dynein arms so lead to restriction of sliding movement of flagellar fiber. Gossypol may inhibits cAMP formation which subsequently decreases sperm motility characteristics [26]. Results of [27] showed that there were a significant increase in primary and secondary sperm abnormalities in bulls fed with gossypol for 28 and 56 days, the proximal droplets was significantly higher than other defects.

Results of [28] appeared that when gossypol was incubated with human sperm, promote the formation of reactive Oxygen species due to the presence of high proportions of polyunsaturated fatty acids (PUFAs) in the phospholipid fraction of spermatozoa membrane. The PUFAs increases the susceptibility of cells to free radicals and lipid peroxidation, which the cellular structure, motility and metabolic functions of the sperm can be impaired as a result of lipid peroxidation caused by ROS [29]. Also, Study of [30] showed that the abnormal morphological changes in spermatogenic cells 
and spermatozoa induced by gossypol were due to decreasing the amount of tubulin and dynein in spermatocyte and spermatid and inhibiting the transformation from round to elongated head spermatid. An increase in percentage of sperm agglutination as showed in the present study may explained by increasing in the production of antisperm antibodies within the testicular secretions. Decreasing of fertility rate in both human and laboratory animals was associated with the presence of antisperm antibodies in secretions of reproductive organs and blood [31].

Also, percent of males were significantly decreased in the offspring as compared to the control group in the two extracts, which may exert a significant estrogenic or antiandrogenic activity [32]. However, other substances such as flavonoid phytochemicals, present in the cottonseed affect the sex ratio in favor of male [33]. These results disagree with result of [34] who showed that male rats treated with gossypol had no effect on the outcome of pregnancy, resorption, fetal growth, or malformation rate. Low offspring sex ratio may be associated with endocrine modifications [35]. While, [36] saw that the sperm morphology is an important characteristic of sperm for evaluating male fertility. Since this parameter was decreased in the treated males, they were negatively related to the fertility indices.

\section{References:}

[1] G.O. Adeyemo (2008). Effects of cottonseed cake based diets on haematology and serum biochemistry of egg-type chickens. Int. J. Poult. Sci. 7: 23-27.

[2] J.E. Santos; M. Villasenor; P.H. Robinson; E.J. Depeters and C.A. Holmberg (2003). Type of cottonseed and level of gossypol in diets of lactating dairy cows: plasma gossypol, health and reproductive performance. J. Dairy. Sci. 86: 892-905.

[3] S.L. Mapel (2004). Effect of cottonseed meal consumption on performance of female fallow deer. M,Sc. Thesis. Texas A and M University.

[4] H.L. Chakravarty (1976). Plant Wealth of Iraq. A dictionary of economic plants.
Vol. 1. Ministry of Agriculture and Agrarian Reform. Baghdad. Pp: 505.

[5] K.S. Rathore (2007). Reducing gossypol in cotton seed may improve human nutrition. ISB News paper. (www.isb.vt.edu).

[6] F.A. Blouin; Z.M. Zarins and J.P. Cherry, (1981). Role of flavonoids in the production of color in biscuits prepared with wheat and cottonseed flours. J. Food. Sci. 46: 226-231.

[7] R.W. Brueggemeier (2003). Male sex hormones, analogs and antagonists. In: Burger's Medicinal Chemistry and Drug Discovery. Abraham, D. (ed.). Vol.3. $6^{\text {th }}$ ed. John Wiley and Sons, New York. Pp: 674-746.

[8] M.A. Hadley; Y.C. Lin; M. Dym, (1981). Effects of gossypol on the reproductive system of male rats. J. Androl. 2: 190-199.

[9] O. Porat (1990). Effects of gossypol on the motility of mammalian sperm. Mole. Reprod. Develop. 25: 400 - 408.

[10] K.D. Thomas; A.E. Caxton-Martins; A.A. Elujoba and O.O. Oyelola (1991). Effects of an aqueous extract of cottonseed (Gossypium barbadense Linn.) on adult male rats. Advances in Contraception. 7: 353-362.

[11] R.J. Hron; M.S. kuk; G. Abraham; P.J. Wan (1994). Ethanol extraction of oil, gossypol and aflatoxin from cottonseed. J. Amer. Oil. Chem. Soc. 71: 417-421.

[12] M-B.M-R. Fakhrildin (2005). Effect of cumulus cell co-culture and protein supplement on success of in vitro fertilization and development of preimplanted embryos in mice. SQU. J. Sci. 10: 31-41.

[13] A. Hinting (1989). Methods of semen analysis. In: assessment of human sperm fertilizing ability. Ph.D. thesis, University of Michigan Stares.

[14] W.C.L. Ford (2006). Glycolysis and sperm motility: does a spoonful of sugar help the flagellum go round? Hum. Reprod. Upd. 12: 269-274.

[15] O.H. Siegmund (1979). Reproductive and urinary system. In: The merck veterinary manual. Siegmand, O.H. and Fraser, C.M.(ed.). Published by merck and Co.Inc.Rahway, N.J. USA. Pp: 792-892. 
[16] M.M. Seibel and M. Zilberstain. (1995). The diagnosis of male infertility by semen quality. The shape of sperm morphology. Hum. Reprod.10: 247-252.

[17] 17 A. Amini and F. Kamkar (2005). The effects of gossypol on spermatogenesis in NMRI mice. Iran. J. Sci. and Technol. Trans. 29: 123-133.

[18] A.K. Farrag; H.I.H. Ismail; E.A. Khalifa and M.M. El- Gamal (2007). The possible synergistic effect of gossypol (cottonseed oil) and Schistosomiasis mansoni on the male reproductive organs in experimenting infected mice. Tanta Medical Sci. J. 2: 78-91.

[19] J. Alexander; D. Benford; A. Cockburn; J-P. Cravedi; E. Dogliotti; A.D. Domenico; M.L. Fernandez-Cruz; P. Füest; J. FinkGremmels (2008). Gossypol as undesirable substance in animal feed. EFSA J. 908: $1-55$.

[20] A.M. Matsumoto (1990). Effects of chronic testosterone administration in normal men: safety and efficacy of high dosage testosterone and parallel dosedependent suppression of luteinizing hormone, follicle-stimulating hormone, and sperm production. J. Clin. Endocrinol. Metab. 70: 282-287.

[21] N. Islam and P.J. Trainer (1998). The hormonal assessment of the infertile male. Review. British. J. Urol. 82: 69-75.

[22] C.C. Jr. Chase; P. Bastidas; J.L. Ruttle; C.R. Long and R.D. Randel (1994). Growth and reproductive development in braham bulls fed diets containing gossypol. J. Anima. Sci. 72: 445-450.

[23] H. Breitbart; S. Rubinstein; L. NassArden (1984). Effect of gossypol acetic acid on calcium transport and ATPase activity in plasma membranes from ram and bull spermatozoa. Int. J. Androl. 7: 439-447.

[24] R. D. Randel; C.C.Jr. Chase and S.J. Wyse (1992). Effects of gossypol and cottonseed products on reproduction of mammals. J. Anim. Sci. 70. 1628.

[25] C.S. Teng (1995). Biological activity in the repopulation rat spermatocyte after withdrawal of gossypol treatment. V. inhibition and recovery of microtubular dynein. Contraception. 51:313-318.
[26] P.M. Zavos and N. Zarmakoupis-Zavos (1996). The inhibitory effects of gossypol on human sperm motility characteristics: possible modes of reversibikity of those effects. The Tohoku. J. Experim. Med. 179: 167-175.

[27] M.E. Hassan; G.W. Smith; R.S. Ott; D.B. Faulkner; L.D. Firkins; E.J. Ehrhart; D.J. Schaeffer (2004). Reversibility of the reproductive toxicity of gossypol in peripubertal bulls. Theriogenol. 61: 11711179.

[28] A. de Peyster; A. Quintanilla; L. Packer and M.T. Smith (1984). Oxygen radical formation induced by gossypol in rat liver microsomes and human sperm. Biochem. Biophys. Res. Commun. 118: 573-579.

[29] D. Sanocka and M. Kurpisz (2004). Reactive oxygen species and sperm cells. Reprod. Biol. Endocrinol. 2: 12-19.

[30] Y.-L. Shi; J-P. Bai and W-P. Wang (2003). Ion-channels in human sperm membrane and contraceptive mechanisms of male antifertility compounds derived from Chinese traditional medicine. Acta. Pharmacol. Sin. 24 : 22-30.

[31] M. Waziri and O.E. Fayemi (2000). Seroprevalence of sperm antibodies in goats. Vet. Arhiv. 70: 95-102.

[32] E.C. Alexopoulos and Y. Alamanos (2007). Secondary sex ratio Greece: evidence of an influence by father's occupational exposure. Hum. Reprod. 22: 2999-3001.

[33] J. Rinchard; K.J. Lee; S. Czesny; A. Ciereszko; K. Dabrowski (2003). Effect of feeding cottonseed meal- containing diets to broodstock rainbow trout and their impact on the growth of their progenies. Aquacult. 227: 77-87.

[34] A. R. Beaudoin, (1985). The embryotoxicity of gossypol. Teratol. 32: 251-257.

[35] W.H. James (2006). Offspring sex ratios at birth as markers of paternal endocrine disruption. Environ. Res. 100: 77-85.

[36] D.Y. Liu and H.W.G. Baker (1992). Morphology of spermatozoa bound to the zona pellucida of human oocytes that failed to fertilize in vitro. J. Fertil. Reprod. 94: 71-84. 


\section{الخلاصة}

اعطي نوعين من مستخلصـات بذور القطــن الكحـــولي

و المائي وبجر عتين 20 ملغم/ كغم فمويا لــذكور الفئـران

لفترة ستة اسابيع لدر سة تأثثير هم على بعض معالم النطف. بينت النتائج بان جرعة 20 و 40 ملغم اكغم/يـوم مسـن المستخلص المائي و الكحولي سبيت انخفاض عالي المعنوية

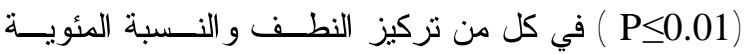
لحركتها و النسبة المئوية للحركة الخطية لها . بينما اظهـرت نتائج النسب المئوية لاشكال النطف غير الـسوية لمجــاميع المعاملة 20 و 40 ملغم اكغم للمستخلص الكحولي و المسائي

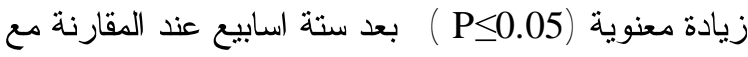
مجمو عة السيطرة.

اظهرت النتـائج حــصول زيــادة عاليــة المعنويـة

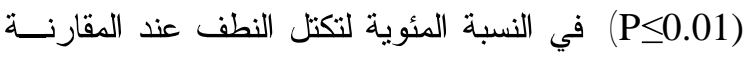

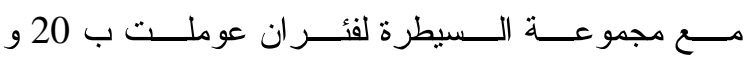
40 ملغم /كغم / يوم من المستخلص الكحولي والمائي . المفاتيح التصنيفية : مستخلصات بذور القطن و الفئـران و فحص وظيفة الحيامن و التكاثز. 